\title{
Dietary supplementation of Agaricus bisporus stalk meal on growth performance, carcass and organ traits, meat quality, cecum mesophilic aerobic bacteria counts and intestinal histology in broiler chickens
}

\author{
Aydin Altop ${ }^{*}$ (D) Isa Coskun² Ayse Gul Filik ${ }^{2}$ (i) Huseyin Cayan ${ }^{2}$ (i) Ahmet Sahin AD $^{-10}$ \\ Emrah Gungor ${ }^{1}$ (D) Guray Erener $^{1}$ (D)
}

'Department of Animal Science, Faculty of Agriculture, Ondokuz Mayis University, 55139, Samsun, Turkey. E-mail: aaltop@omu.edu.tr. ${ }^{*}$ Corresponding author.

${ }^{2}$ Department of Agricultural Biotechnology, Faculty of Agriculture, Kırşehir Ahi Evran University, Kırşehir 40100, Turkey.

\begin{abstract}
Effects of dietary Agaricus bisporus mixture or stalk or cap on growth performance, carcass components and some meat quality parameters, mesophilic aerobic bacterial counts, and intestinal histomorphology in broiler chickens were investigated. Two hundred and forty one-day-old male Ross 308 broiler chickens were divided into 4 experimental groups with 4 replicates, each including 15 birds. Chickens were fed with basal diet (C), mushroom mixture (MM, $10 \mathrm{~g}$ stalk $+10 \mathrm{~g}$ cap $/ \mathrm{kg}$ diet), mushroom stalk (MS, $20 \mathrm{~g} / \mathrm{kg}$ diet) and mushroom cap (MC, 20 $\mathrm{g} / \mathrm{kg}$ diet). Feed conversion ratio $(F C R)$ was improved $(P<0.01)$ by dietary MS while feed intake $(F I)$ decreased $(P<0.01)$ in all treatment groups compared to control. However, body weight gain $(B W G)$ was decreased $(P<0.01)$ by MC inclusion. Mushroom supplemented groups had higher $(P<0.05)$ mesophilic aerobic bacteria in the cecum. MS inclusion increased villus height to crypt depth ratio in the jejunum $(P$ $<0.01)$ and villus height in the ileum $(P<0.01)$ and jejunum $(P<0.05)$. MC increased $(P<0.01)$ crypt depth in the jejunum. There were no statistical differences among groups for carcass components $(P>0.05)$. The $L^{*}$ values were decreased $(P<0.01)$ in thigh meat but increased $(P<0.01)$ in breast meat by mushroom inclusion. The $a^{*}$ values were decreased $(P<0.01)$ and $b^{*}$ values were increased $(P<0.05)$ in both thigh and breast meat with mushroom addition to diet. The obtained results indicated that A. bisporus stalk meal at an inclusion level of $20 \mathrm{~g} /$ $\mathrm{kg}$ of diet had favourable effects on growth performance with higher feed efficiency, improved intestinal morphology with higher villus height and increased meat quality of broiler chickens.
\end{abstract}

Key words: mushroom, feed efficiency, villus height, feed additives, by-product.

Efeitos da suplementação dietética de farelo de caule de Agaricus bisporus no desempenho de crescimento, características de carcaça e órgãos, qualidade da carne, contagem de bactérias aeróbias mesófilas cecais e histologia intestinal em frangos de corte

RESUMO: Foram investigados os efeitos da mistura dietética de Agaricus bisporus ou talo ou tampa sobre o desempenho de crescimento, componentes da carcaça e alguns parâmetros de qualidade da carne, contagens de bactérias aeróbias mesofilicas e histomorfologia intestinal em frangos de corte. Duzentos e quarenta frangos de corte Ross 308 de um dia de idade foram divididos em quatro grupos experimentais com quatro repetições, cada um incluindo 15 aves. Galinhas alimentadas com dieta basal (C), mistura de cogumelos (MM, $10 \mathrm{~g}$ caule $+10 \mathrm{~g}$ cap $/ \mathrm{kg}$ de dieta), caule de cogumelo (MS, $20 \mathrm{~g} / \mathrm{kg}$ dieta) e cogumelo (MC, $20 \mathrm{~g} / \mathrm{kg}$ dieta). A taxa de conversão alimentar (FCR) foi melhorada $(P<0.01)$ por $M S$ dietético enquanto o consumo de ração $(F I)$ diminuiu $(P<0.01)$ em todos os grupos de tratamento em comparação com o controle. No entanto, o ganho de peso corporal $(B W G)$ foi diminuído $(P<0.01)$ pela inclusão de MC. Os grupos suplementados com cogumelos apresentaram maiores $(P<0.05)$ bactérias aeróbias mesofilicas no ceco. A inclusão de MS aumentou a proporção entre a largura das vilosidades e a profundidade da cripta no jejuno $(P<0.01)$ e o comprimento das vilosidades no ileo $(P<0.01)$ e jejuno $(P<0.05)$. MC aumentou $(P<0.01)$ a profundidade de cripta no jejuno. Não houve diferença estatística entre os grupos nos componentes da carcaça $(P>$ 0.05). Os valores $L *$ diminuiram $(P<0.01)$ na carne da coxa, mas aumentaram $(P<0.01)$ na carne de peito com a inclusão de cogumelos. Os valores de $a^{*}$ diminuíram $(P<0.01)$ e os valores de $b^{*}$ aumentaram $(P<0.05)$ em ambas as coxas e peitos pela adição de cogumelos à dieta. Os resultados obtidos indicaram que a farinha de colmo de A. bisporus com um nível de inclusão de $20 \mathrm{~g} / \mathrm{kg}$ de dieta teve efeitos favoráveis no desempenho do crescimento com maior eficiência alimentar, melhorou a morfologia intestinal com maior comprimento de vilosidade e aumentou a qualidade da carne de frangos de corte.

Palavras-chave: cogumelo, eficiência alimentar, comprimento de vilosidades, aditivos alimentares, subproduto.

\section{INTRODUCTION}

Mushroom production rapidly increased in Turkey to more than 49,000 tons and reached more than 11.8 million tons annually around the world (FAO, 2019). As a source of food, edible mushrooms contain protein, sugar, dietary fibre, several vitamins and minerals, along with other health beneficial

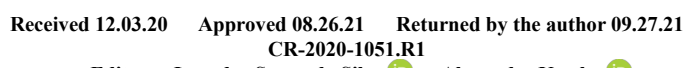


substances such as antioxidants, antimicrobials, etc (ASADI-DIZAJI et al., 2017). Thus, edible mushrooms have important potential in filling nutritional gaps in human nutrition.

The bottom part of the mushroom stalks are usually discarded during the packing process in mushroom production facilities. This quantity of by-product is equal to $20 \%$ of total mushroom production. Its nutritional content is quite reasonable with respect to crude protein, metabolizable energy, and other health beneficial substances since their extracts are sold at higher prices in chemist or health support markets. If these by-products are not used in any field, they will cause environmental pollution (YANG et al., 2021). Therefore, use of the mushroom stalks in animal nutrition will help to reduce environmental pollution.

Mushrooms contain important bioactive phenolic components such as benzoic acid derivatives (p-hydroxybenzoic acid, protocatechuic acid, and gallic acid) and cinnamic acid derivatives (cinnamic acid, p-cou-maric acid, ferulic acid and chlorogenic acid) (RAMOS et al., 2019). Mushrooms have antioxidant, immunostimulatory, anti-inflammatory, antibacterial, antiviral and hypocholesterolemic effects on broiler chickens (BEDERSKAŁOJEWSKA et al., 2017). SHAMSI et al. (2015a) reported that dietary $20 \mathrm{~g} / \mathrm{kg} \mathrm{A}$. bisporus improved body weight gain, feed conversion ratio, and reduced serum cholesterol level in broiler chickens. Moreover, dietary inclusion of $20 \mathrm{~g} / \mathrm{kg}$ A. bisporus increased Lactobacillus spp. and Bifidobacteria counts in the cecum of broilers (GIANNENAS et al., 2010b). The intestinal morphology was improved by dietary mushroom stalk supplementation in broiler chickens (HSIEH et al., 2021). A recent study also showed that dietary $20 \mathrm{~g} / \mathrm{kg}$ A. bisporus stem residues improved the utilisation of protein and total energy, and increased antioxidant capacity in laying hens (YANG et al., 2021). These positive effects indicate that $A$. bisporus could have potential as a functional feed additive for broiler nutrition.

Previous studies showed that cap and stalk parts of $A$. bisporus have different chemical compositions. The stalk of $A$. bisporus has higher carbohydrate, polysaccharide, phenolic compounds and calcium content, while the cap has higher crude protein, ash and potassium content (NASIRI et al., 2013; CHERNO et al., 2016). WU et al. (2016) also reported that $A$. bisporus stalk has more phenolic compounds and radical scavenging activity than the cap. These nutritional differences indicate that the stalk of $A$. bisporus may be more beneficial for broiler chickens compared to the cap. However, there is lack of research about comparisons of the effect of A. bisporus cap and stalk parts on broiler chickens. Therefore, this study evaluated the effect of cap and stalk parts of $A$. bisporus on growth performance, carcass components, intestinal morphology and meat quality traits in broiler chickens.

\section{MATERIALS AND METHODS}

All experimental procedures were conducted in accordance with the guidelines of Kirsehir Ahi Evran University Local Ethics Committee. A total of 240 one-day-old male Ross 308 broiler chicks weighing $42 \pm 0.02 \mathrm{~g}$ were used in this study. All birds were fed on a starter diet at 1-21 days old, grower diet at 22-35 days old, and finisher diet at 36-42 days old (Table 1). Diets were provided ad libitum in mash form and prepared daily. Broiler chickens were divided into 4 experimental groups with 4 replicate cages, each including 15 birds. Dietary treatments were control (C, basal diet without A. bisporus mushroom), A. bisporus mushroom mixture (MM, per kg experimental diet supplemented with $10 \mathrm{~g}$ mushroom stalk $+10 \mathrm{~g}$ mushroom cap), $A$. bisporus mushroom stalk (MS, per kg experimental diet supplemented with $20 \mathrm{~g} \mathrm{MS}$ ) and A. bisporus mushroom cap (MC, per experimental diet supplemented with $20 \mathrm{~g}$ MC). Proximate composition of mushroom stalk, mushroom cap and mushroom stalk and cap (1:1 ratio) were measured according to AOAC Official Method 976.06 for CP, AOAC Official Method 920.29 for EE, and AOAC Official Method 942.05 for ash (AOAC, 2000). Neutral detergent fiber (NDF) and acid detergent fiber (ADF) analyses were conducted according to VAN SOEST et al. (1991) using the ANKOM ${ }^{200 / 220}$ fiber analyzer (ANKOM corporation ${ }^{\circledR}$ Technology Fairport, NY). Measurement of each sample was conducted 3 times and the average was taken. CP, EE, Ash, ADF and NDF of different parts of $A$. bisporus mushroom in \% DM basis were found to be 42.03, 1.37, 13.57, 38.32 and 13.32 for mushroom stalk, 41.20, 1.90, 8.48, 34.42 and 14.52 for mushroom cap, and 41.61, 1.63, $11.02,36.37$ and 13.92 for mushroom stalk and cap (1:1 ratio), respectively.

All birds were subjected to the management practices as mentioned in the Management Guide for Ross 308 broilers (AVIAGEN, 2014). Birds were fed by using cylindrical hanging feeders and watered by hanging drinkers. Feeder and drinker spaces were $2 \mathrm{~cm}$ per bird. Lights were on continuously for the first $3 \mathrm{~d}$ after hatching, after which a 23L:1D lighting schedule using 2 fluorescent bulbs was maintained for 
Table 1 - Ingredient composition and chemical analysis of basal diet used in the experiment $\left(\mathrm{g} \cdot \mathrm{kg}^{-1}\right.$, as fed on basis).

\begin{tabular}{|c|c|c|}
\hline Ingredients & $\begin{array}{l}\text { Starter diet } \\
\text { (0-21 days) }\end{array}$ & $\begin{array}{l}\text { Grower diet } \\
\text { (21-42 days) }\end{array}$ \\
\hline Maize & 400 & 300 \\
\hline Soybean meal (\%46) & 188 & 120 \\
\hline Full-fat soybean & 100 & - \\
\hline Maize bran & 126 & 151 \\
\hline Sunflower meal (\%36) & 100 & 82 \\
\hline Wheat & - & 120 \\
\hline Wheat bran & - & 75 \\
\hline Meat and bone meal & 35 & 30 \\
\hline Corn meal & 9.30 & 32.26 \\
\hline Vegetable oil & 25.0 & 60.0 \\
\hline Limestone & 6.96 & 15.0 \\
\hline Dicalcium phosphate & - & 1.00 \\
\hline Sodium bicarbonate & - & 2.00 \\
\hline DL-methionine $(\% 88)$ & 2.50 & 1.74 \\
\hline L-lysine $(\% 99)$ & 2.24 & 4.50 \\
\hline Salt & 2.50 & 2.50 \\
\hline Vitamin, Mineral premix ${ }^{*}$ & 2.50 & 2.50 \\
\hline Coccidial & & 0.50 \\
\hline Total & 1000 & 1000 \\
\hline \multicolumn{3}{|c|}{ 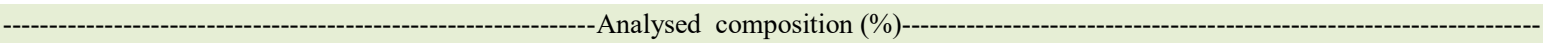 } \\
\hline Crude protein & 23.0 & 20.0 \\
\hline Ether extract & 6.59 & 8.50 \\
\hline Crude fiber & 5.45 & 6.15 \\
\hline Ash & 6.57 & 6.69 \\
\hline \multicolumn{3}{|c|}{ 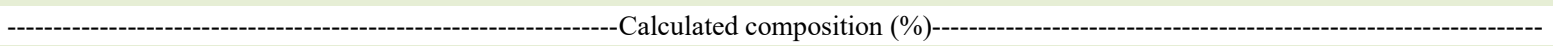 } \\
\hline Metabolizable energy, $\mathrm{MJ} \cdot \mathrm{kg}^{-1}$ & 12.56 & 13.39 \\
\hline Lysine & 1.30 & 1.20 \\
\hline Methionine & 0.60 & 0.50 \\
\hline Methionine-cysteine & 0.77 & 0.62 \\
\hline Threonine & 0.77 & 0.51 \\
\hline Tryptophan & 0.26 & 0.19 \\
\hline Calcium & 0.96 & 0.98 \\
\hline Total phosphorus & 0.78 & 0.70 \\
\hline Available phosphorus & 0.50 & 0.45 \\
\hline Sodium & 0.27 & 0.26 \\
\hline Chlorine & 0.22 & 0.22 \\
\hline
\end{tabular}

"Contained per kilogram of premix: retinyl acetate, $3.60 \mathrm{mg}$; cholecalciferol, $0.06 \mathrm{mg}$; DL- $\alpha$-tocopherol acetate, $40 \mathrm{mg}$; menadione, 4 $\mathrm{mg}$; thiamine, $3 \mathrm{mg}$; riboflavin, $6 \mathrm{mg}$; niacin, $25 \mathrm{mg}$; calcium-D-pantothenate, $10 \mathrm{mg}$; pyridoxine, $5 \mathrm{mg}$; cyanocobalamin, $0.03 \mathrm{mg}$; Dbiotin, $0.05 \mathrm{mg}$; folic acid, $1 \mathrm{mg}$; Mn, $80 \mathrm{mg}$; Zn, $60 \mathrm{mg}$; Fe, $60 \mathrm{mg}$; Cu, $5 \mathrm{mg}$; Co, $0.2 \mathrm{mg}$; I, $1 \mathrm{mg}$; Se, $0.15 \mathrm{mg}$; choline chloride, 200 mg.

${ }^{1}$ Metabolizable Energy was calculated based on chemical composition.

the duration of the experiment. Ambient temperature was gradually decreased from $33{ }^{\circ} \mathrm{C}$ at $7 \mathrm{~d}$ to $21{ }^{\circ} \mathrm{C}$ until 21 days old and, then, kept constant.

During the experimental period, health status of broiler was checked daily, whereas body weight gain (BWG) and feed intake (FI) were measured weekly. Feed conversion ratio (FCR) was calculated as the ratio of FI to BWG. At the end of the experiment, two birds from each replication representing the mean weight in each treatment $(8$ birds for each treatment and total of 32 birds) were slaughtered to determine weights of edible inner 
organs of the carcass (gizzard + heart + liver), abdominal fat and gastrointestinal tract (gut) and length of gut. Relative weights and lengths (when appropriate) of carcass and non-carcass parts were calculated as percentages of body weight (BW, $\mathrm{g}$ or $\mathrm{cm} / 100 \mathrm{~g} \mathrm{BW})$. Carcass yield was calculated by dividing carcass weight by live weight. Left breast (pectoralis major) and thigh (ilio tibialis) samples were collected at $12 \mathrm{~h}$ post mortem for evaluation of $\mathrm{pH}$, water holding capacity (WHC) and colour traits. These samples were kept frozen $\left(-20^{\circ} \mathrm{C}\right)$ until analyses.

The meat colour (HUNT et al., 1991) values representing lightness $\left(L^{*}\right)$, redness $\left(a^{*}\right)$ and yellowness $\left(b^{*}\right)$ were measured at $12 \mathrm{~h}$ post mortem using a Konica Minolta colorimeter (Konica Minolta CR-400 colorimeter, Sensing Inc, Japan) in breast and thigh samples. Meat colour was evaluated at three points on the skinless left thigh and breast. Before measurements, the colorimeter was calibrated throughout the study using a white and pink ceramic tile. Meat $\mathrm{pH}$ was also measured at the same points and times using a pH meter (Model PC 510, Cyber scan, Singapore) equipped with an insertion electrode (S175CD Spear Tip; Sensorex, Garden Grove, CA,USA) and calibrated with buffers at $\mathrm{pH} 4.01,7.01$ and 10.1 (Mettler Toledo, Tampa, FL, USA) at ambient temperature. The WHC of meats was measured by using a press technique explained by OZTAN \& VURAL (1993) with a slight modification. One $g$ sample was placed on filter paper (Whatman No. 1), which was set between two Plexiglas plates (Ildam Cam AS, Ankara, Turkey) and pressed for 20 minutes with a $1 \mathrm{~kg}$ weight. The outline areas of the expressible juice and the pressed meat film were traced, and the two areas were measured using a Placom Digital Planimeter (Model KP-90, Sokkisha Planimeter Inc., Kanagawa, Japan). Then, WHC was calculated as the ratio of meat film area to total juice area.

Cecum samples, which were collected post mortem, were transferred under aseptic conditions into sterile glass tubes and kept on ice until subsequent inoculation into agars. One gram of wet sample was diluted with $10 \mathrm{ml}$ of sterilized distilled water, of which $1 \mathrm{ml}$ was transferred into $9 \mathrm{ml}$ of MRD (Merck, Darmstadt, Germany, 1.12535). Samples were serially diluted from $10^{-1}$ to $10^{-9}$. One-tenth millilitre of each diluted sample was plated on the plate count agar (Merck, Darmstadt, Germany, 1.05463) for the enumeration of mesophilic aerobic bacteria populations. The plates were incubated at $37{ }^{\circ} \mathrm{C}$ for $48 \mathrm{~h}$. Then colonies were counted and the average number of live bacteria was calculated based on wet digesta weight $(\mathrm{g})$ of cecum content. Mesophilic aerobic bacteria counts of samples were converted into log colony forming units (CFU g-1).

Duodenum, jejunum and ileum samples were taken and cut into $1.5 \mathrm{~cm}$ pieces for small intestine histomorphology and placed into $10 \%$ formalin for further processing. Tissue sections were placed into tissue cassettes for the dehydration process and were embedded in paraffin blocks, and subsequently cut to 5 - $\mu \mathrm{m}$ thickness and placed on a slide. Each ileal histomorphology tissue sample was prepared and stained with haematoxylin and eosin solution by using standard paraffin-embedding methods (XU et al., 2003). After embedding, villus height and villus width were photographed and evaluated by using an image processing and analysis system via ZEISS Primstar HD light microscope (ZEN 2012 SP2).

\section{Statistical analysis}

The data were analysed by using the Windows version of SPSS 21.0 (SPSS Inc., NY, and USA). For performance data, pen means served as the experimental unit for statistical analysis. For data about relative weights, length of gut, and meat quality traits slaughtered individual birds were considered as the experimental unit. Levene's test and the ShapiroWilk test were firstly used for equality of variance and for normality assumptions, respectively, of the traits (BWG, FI etc.) for the four treatments $(\mathrm{C}, \mathrm{MM}$, $\mathrm{MS}$ and $\mathrm{MC})(\mathrm{P}>0.05)$. Then, one-way ANOVA and Tukey HSD multiple comparison tests were used to determine the differences between experimental groups. Finally, results are presented as means with standard error of the mean (SEM). P-value of less than 0.05 was considered statistically significant.

\section{RESULTS AND DISCUSSION}

The chickens receiving $A$. bisporus supplemented diets had better $(\mathrm{P}<0.01)$ FCR than the birds from the control group at 0-21 days of age (Table 2). However, BWG was decreased with the dietary inclusion of $\mathrm{MC}$ compared to that of birds from other groups at 22-42 days ( $\mathrm{P}<$ $0.05)$ and $0-42$ days $(P<0.01)$. Similarly, the FI of broilers decreased $(\mathrm{P}<0.01)$ in all treatments with mushrooms during the experimental period. The best FCR was obtained by the dietary inclusion of MS (P $<0.01)$. However, there were no differences between $\mathrm{C}$ and $\mathrm{MC}$ groups $(\mathrm{P}>0.05)$. Similar to the results of this study, GIANNENAS et al. (2010a) reported that dietary $20 \mathrm{~g} / \mathrm{kg}$ A. bisporus improved the $\mathrm{BW}$, BWG and FCR in broiler chickens. Dietary $20 \mathrm{~g} /$ 
Table 2 - Effect of dietary inclusion of different mushroom parts on growth performance of broiler chickens.

\begin{tabular}{|c|c|c|c|c|c|c|}
\hline & $\mathrm{C}$ & MM & MS & MC & SEM & $P$ \\
\hline Initial body weight (g) & 42 & 42 & 42 & 42 & 0.02 & NS \\
\hline \multicolumn{7}{|c|}{ 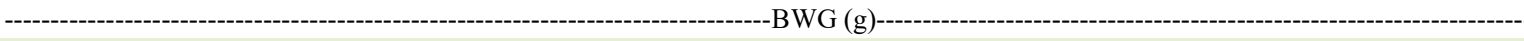 } \\
\hline $0-21$ days & 618 & 629 & 617 & 616 & 3.2 & NS \\
\hline $22-42$ days & $1866^{\mathrm{a}}$ & $1822^{\mathrm{ab}}$ & $1875^{\mathrm{a}}$ & $1786^{\mathrm{b}}$ & 11.4 & ${ }^{*}$ \\
\hline 0-42 days & $2485^{\mathrm{a}}$ & $2452^{\mathrm{ab}}$ & $2509^{\mathrm{a}}$ & $2403^{b}$ & 11.1 & ** \\
\hline \multicolumn{7}{|c|}{ } \\
\hline 0-21 days & $970^{\mathrm{a}}$ & $961^{\mathrm{b}}$ & $900^{\mathrm{b}}$ & $913^{\mathrm{b}}$ & 5.7 & ** \\
\hline $22-42$ days & $3584^{\mathrm{a}}$ & $3485^{\mathrm{ab}}$ & $3463^{\mathrm{b}}$ & $3533^{\mathrm{b}}$ & 14.6 & * \\
\hline 0-42 days & $4554^{\mathrm{a}}$ & $4387^{\mathrm{b}}$ & $4363^{\mathrm{b}}$ & $4446^{\mathrm{b}}$ & 18.5 & ** \\
\hline \multicolumn{7}{|c|}{ 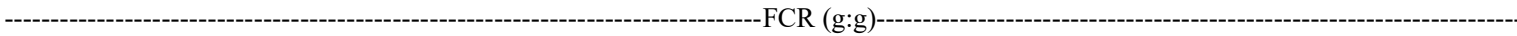 } \\
\hline $0-21$ days & $1.56^{\mathrm{a}}$ & $1.43^{\mathrm{b}}$ & $1.46^{\mathrm{b}}$ & $1.48^{\mathrm{b}}$ & 0.011 & ** \\
\hline $22-42$ days & $1.92^{\mathrm{ab}}$ & $1.91^{\mathrm{ab}}$ & $1.85^{\mathrm{b}}$ & $1.98^{\mathrm{a}}$ & 0.010 & $* *$ \\
\hline 0-42 days & $1.83^{\mathrm{a}}$ & $1.79^{\mathrm{b}}$ & $1.74^{\mathrm{c}}$ & $1.85^{\mathrm{a}}$ & 0.008 & $* *$ \\
\hline
\end{tabular}

${ }^{\mathrm{a}, \mathrm{b}}$ Means in the same row not sharing a common letter are significantly different. NS: Not significant, ${ }^{*}: \mathrm{P}<0.05,{ }^{* *}: \mathrm{P}<0.01$. SEM: Standard error of mean.

Data are means for 4 replicates of 15 broiler chickens.

${ }^{1}$ The dietary treatments were as follows: control (C, basal diet without A. bisporus mushroom), A. bisporus mushroom mixture (MM, basal diet supplemented with $10 \mathrm{~g}$ mushroom stalk+10 g mushroom cap of per $\mathrm{kg}$ feed), A. bisporus mushroom stalk (MS, basal diet supplemented with $20 \mathrm{~g}$ MS of per kg feed) and A. bisporus mushroom cap (MC, basal diet supplemented with $20 \mathrm{~g}$ MC of per kg feed).

$\mathrm{kg}$ A. bisporus increased the crude protein and total energy utilisation in laying hens (YANG et al., 2021). Improvement in the growth performance of broiler chickens can be due to possible increases in nutrient and energy utilisation or both. Moreover, FARD et al. (2014) noted that mushrooms have growth-promoting effect on broiler chickens due to oligosaccharides in the cell wall. Similarly, SHAMSI et al. (2015a) showed improved BWG and FCR and decreased FI in broiler chickens fed with diets supplemented with $20 \mathrm{~g} / \mathrm{kg}$ A. bisporus. However, BWG was decreased by dietary $A$. bisporus cap supplementation in this study. Similarly, KAVYANI \& PORREZA (2012) showed that dietary $20 \mathrm{~g} / \mathrm{kg}$ A. bisporus decreased BWG at 21 days old and worsened the FCR at 42 days old in broiler chickens. Decreased BWG and FI were also reported in broiler chickens receiving diet supplemented with $30 \mathrm{~g} / \mathrm{kg} \mathrm{A}$. bisporus (HAMMO, 2018). Agaricus bisporus has some antinutritional components such as tannins, phytic acid, and oxalates (SHARMA et al., 2008; GAUR et al., 2016). SINGH (2008) reported that phytic acid worsens the growth performance of broiler chickens by decreasing the utilization of amino acid and minerals. Similarly, tannins reduce protein and amino acid utilisation by forming tannin-protein complexes and impair the growth performance of broilers (CHO et al., 2019).
Beneficial effects of $A$. bisporus stalk meal on the growth performance may be due to the improvement in the intestinal morphology. GUNGOR et al. (2021) reported that there is a close relationship between intestinal morphology, the absorption of nutrients in the feed and also growth performance of broiler chickens. Higher villus height indicates healthy intestines and good absorption capacity; although, shorter villus height and deeper crypt can indicate the presence of a toxin (GIANNENAS et al., 2010b). Dietary A. bisporus stalk meal increased villus height in the jejunum and ileum of broilers in the present study (Table 3). Similarly, Pleurotus eryngii stalk residues and Cordyceps militaris waster medium increased villus height to crypt depth ratio in the jejunum of broiler chickens (HSIEH et al., 2021). Improvements of the intestinal morphology in broiler chickens fed with $A$. bisporus stalk meal can be attributed to antioxidant capacity. Indeed, GUNGOR \& ERENER (2020) observed an improvement in intestinal morphology in chickens whose antioxidant capacity was improved. The antioxidative effect of A. bisporus is mainly due to phenolic compounds (SMOLSKAITE et al., 2015) and polysaccharides (SIU et al., 2014). Moreover, A. bisporus stalks is reported to have more polysaccharides, phenolic compounds and antioxidant capacity than the caps 
Table 3 - Effect of dietary A. bisporus mushroom on small intestine morphology of broiler chickens aged 42 days.

\begin{tabular}{|c|c|c|c|c|c|c|}
\hline Parameters $\dagger$ & $\mathrm{C}$ & MM & MS & MC & SEM & $P$ \\
\hline \multicolumn{7}{|c|}{ 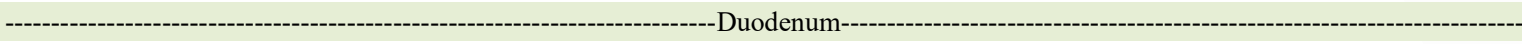 } \\
\hline Villus height $(\mu \mathrm{m})$ & 1436 & 1349 & 1398 & 1369 & 18.9 & NS \\
\hline Crypt depth $(\mu \mathrm{m})$ & 219 & 208 & 213 & 243 & 5.5 & NS \\
\hline $\begin{array}{l}\text { Villus height:Crypt } \\
\text { depth }\end{array}$ & 6.60 & 6.50 & 6.60 & 5.60 & 0.160 & NS \\
\hline \multicolumn{7}{|c|}{ 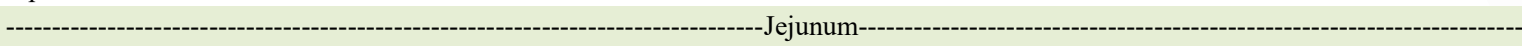 } \\
\hline Villus height $(\mu \mathrm{m})$ & $1242^{\mathrm{bc}}$ & $1180^{\mathrm{c}}$ & $1461^{\mathrm{a}}$ & $1363^{\mathrm{ab}}$ & 22.10 & ${ }^{* *}$ \\
\hline Crypt depth $(\mu \mathrm{m})$ & $156^{\mathrm{b}}$ & $167^{\mathrm{b}}$ & $167^{\mathrm{b}}$ & $204^{a}$ & 4.50 & ** \\
\hline $\begin{array}{l}\text { Villus height:Crypt } \\
\text { depth }\end{array}$ & $7.90^{\mathrm{ab}}$ & $7.10^{\mathrm{b}}$ & $8.70^{\mathrm{a}}$ & $6.70^{\mathrm{b}}$ & 0.210 & $* *$ \\
\hline \multicolumn{7}{|c|}{ 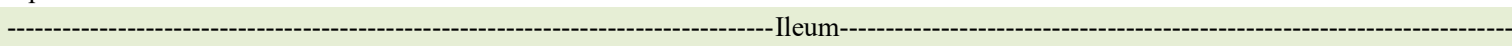 } \\
\hline Villus height $(\mu \mathrm{m})$ & $1013^{b}$ & $889^{\mathrm{b}}$ & $1027^{\mathrm{a}}$ & $974^{\mathrm{b}}$ & 13.1 & $*$ \\
\hline Crypt depth $(\mu \mathrm{m})$ & 183 & 158 & 161 & 177 & 3.6 & NS \\
\hline $\begin{array}{l}\text { Villus height:Crypt } \\
\text { depth }\end{array}$ & 5.50 & 5.60 & 6.30 & 5.50 & 0.130 & NS \\
\hline
\end{tabular}

${ }^{\mathrm{a}, \mathrm{b}, \mathrm{c}}$ Means in the same row not sharing a common letter are significantly different. NS: Not significant, ${ }^{*}: \mathrm{P}<0.05,{ }^{* *}: \mathrm{P}<0.01$. SEM Standard error of mean.

$\uparrow$ The values are means of the 4 replicates (pens).

${ }^{1}$ The dietary treatments were as follows: control (C, basal diet without A. bisporus mushroom), A. bisporus mushroom mixture (MM, basal diet supplemented with $10 \mathrm{~g}$ mushroom stalk $+10 \mathrm{~g}$ mushroom cap of per $\mathrm{kg}$ feed), A. bisporus mushroom stalk (MS, basal diet supplemented with $20 \mathrm{~g}$ MS of per $\mathrm{kg}$ feed) and $A$. bisporus mushroom cap (MC, basal diet supplemented with $20 \mathrm{~g} \mathrm{MC} \mathrm{of} \mathrm{per} \mathrm{kg} \mathrm{feed).}$

(CHERNO et al., 2016; WU et al., 2016). This can explain the beneficial effect of $A$. bisporus stalk meal on the intestinal morphology; although, cap meal did not affect the intestinal morphology in the present study.

The negative effect of $\mathrm{MC}$ on growth performance in broiler chickens may be due to the adverse effect on intestinal morphology in this study. Surprisingly, dietary $A$. bisporus cap meal increased the crypt depth in the jejunum of broiler chickens compared to other treatment groups. Deeper crypts are undesirable in broiler chickens as more energy is needed for the proliferation of intestinal cells (HSIEH et al., 2021) and it also might decrease the absorption capacity by decreasing the absorption area in the intestines (XU et al., 2003). This result is inconsistent with the findings of the studies in which $A$. bisporus did not affect the intestinal morphology of broilers (GIANNENAS et al., 2010b; KAVYANI et al., 2014). The worsened intestinal morphology may be due to the antinutritional compounds (tannins, phytic acid, and oxalates) in A. bisporus (SHARMA et al., 2008; GAUR et al., 2016). The antinutritional compounds in A. bisporus cap or stalk were not analysed in the present study. Further studies are needed to investigate the underlying reasons for detrimental effects of $A$. bisporus on intestinal morphology of broiler chickens.

The beneficial effect of $A$. bisporus stalk meal on the intestinal microflora can be another reason for the improvement in intestinal morphology. JAZI et al. (2017) noted that healthy intestinal microflora is crucial to maintain healthy intestinal morphology in broiler chickens. In this study, the total aerobic bacteria increased in the cecum of broiler chicks (Figure 1). Mushrooms have prebiotic effects due to considerable amounts of polysaccharides such as chitin, hemicellulose, $\alpha$ - and $\beta$-glucans, mannans, xylans and galactans (SINGDEVSACHAN et al., 2016). ŠPOLJARIĆ et al. (2015) reported that A. bisporus increased Lactobacillus spp., and decreased Escherichia coli and Enterobacteriaceae in rectal swabs from broiler chickens. GIANNENAS et al. (2010b) also noted that $A$. bisporus increased the Lactobacillus spp. and Bifidobacteria counts in the cecum but also showed no change in the total aerobic and anaerobic bacteria counts based on dietary A. bisporus. These contradictions may be due to the difference in antimicrobial components and antimicrobial activity of the mushrooms in the studies.

Ciência Rural, v.52, n.6, 2022. 


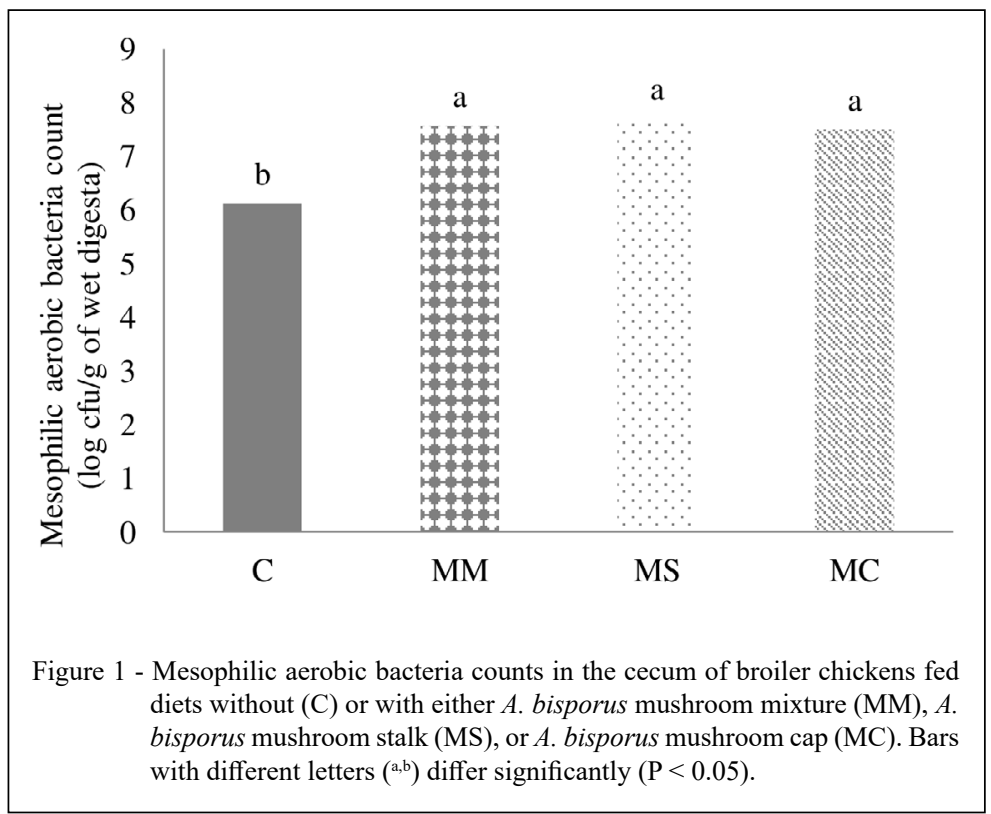

Carcass yield, edible inner organs, gut weight and length are presented in table 4 . There were no differences between the treatment groups in terms of the examined parameters $(\mathrm{P}>0.05)$. These findings are similar to the studies in which the dietary inclusion of mushroom powders or their extracts did not affect bursa fabricius, abdominal fat carcass yield, gut weight and length, and pancreas (TOGHYANI et al., 2012). Similarly, SHAMSI et al. (2015b) reported no change in the weights of proventriculus and pancreas in broiler chicks with dietary A. bisporus supplementation.

Meat colour is one of determining factors for customer preferences in buying poultry meat products. In the current study, the colour characteristics, $\mathrm{WHC}$, and $\mathrm{pH}$ for all treatments were within the normal range. KANNAN et al. (1997) categorized meat samples according to $\mathrm{L}^{*}$ values as lighter than normal, $\mathrm{L}^{*}>53$; normal, $48<\mathrm{L}^{*}>51$; and darker than normal $\mathrm{L}^{*}<46$. Our meat samples were

Table 4 - Effects of dietary inclusion of the different parts of $A$. bisporus mushroom on carcass yield (\%) and some body components (g or $\mathrm{cm} 100 \mathrm{~g}-1$ body weight) of broiler chickens aged 42 days.

\begin{tabular}{|c|c|c|c|c|c|c|}
\hline & $\mathrm{C}$ & MM & MS & $\mathrm{MC}$ & SEM & $P$ \\
\hline Carcass yield & 73 & 73 & 74 & 73 & 0.2 & NS \\
\hline Edible inners organs & 1.56 & 1.64 & 1.60 & 1.56 & 0.015 & NS \\
\hline Abdominal fat & 1.66 & 1.71 & 1.66 & 1.67 & 0.014 & NS \\
\hline Bursa fabricius & 0.89 & 0.94 & 0.95 & 0.93 & 0.013 & NS \\
\hline Pancreas & 0.72 & 0.76 & 0.80 & 0.79 & 0.014 & NS \\
\hline Proventriculus & 0.56 & 0.55 & 0.54 & 0.56 & 0.007 & NS \\
\hline Gut weight $\dagger$ & 3.59 & 3.64 & 3.56 & 3.62 & 0.027 & NS \\
\hline Gut length $\dagger$ & 8.38 & 8.41 & 8.45 & 8.48 & 0.030 & NS \\
\hline
\end{tabular}

NS: Not significant. SEM: Standard error of mean.

$\dagger$ The values are means of the 4 replicates (pens).

${ }^{1}$ The dietary treatments were as follows: control (C, basal diet without $A$. bisporus mushroom), A. bisporus mushroom mixture (MM, basal diet supplemented with $10 \mathrm{~g}$ mushroom stalk+10 g mushroom cap of per $\mathrm{kg}$ feed), A. bisporus mushroom stalk (MS, basal diet supplemented with $20 \mathrm{~g}$ MS of per $\mathrm{kg}$ feed) and A. bisporus mushroom cap (MC, basal diet supplemented with $20 \mathrm{~g} \mathrm{MC}$ of per $\mathrm{kg}$ feed). 
not considered pale or dark according to this category when measured using a reflectance colorimeter in the breast meat. The $\mathrm{L}^{*}$ values of breast meat in this study were above 52.39, which is in the normal range (Table 5). The $\mathrm{L}^{*}$ value was increased $(\mathrm{P}<0.01)$ in breast meat of the MS group but was decreased in thigh meat of MS and MM groups compared to $\mathrm{C}$ group. All dietary treatments decreased $(\mathrm{P}<0.01)$ the $\mathrm{a}^{*}$ values in breast and thigh meat. Dietary $\mathrm{MC}$ increased $(\mathrm{P}<0.05)$ the $\mathrm{b}^{*}$ values in breast and thigh meat compared to $\mathrm{C}$ group. The $\mathrm{pH}$ of breast meat was increased by dietary $\mathrm{MM}$ and $\mathrm{MC}$; although, thigh meat $\mathrm{pH}$ was increased by dietary $\mathrm{MM}$ and MS. There were no differences in WHC between the treatment groups. Similarly, dietary $20 \mathrm{~g} / \mathrm{kg}$ P. eryngii stalk residue increased $\mathrm{pH}, \mathrm{b}^{*}$ values and decreased $\mathrm{L}^{*}$ values in breast and thigh meat of broiler chickens (LEE et al., 2012). Contrary to the results of the study, $\mathrm{a}^{*}$ values and WHC were increased by dietary $20 \mathrm{~g} /$ $\mathrm{kg} P$. eryngii stalk residue given to broiler chickens (LEE et al., 2012).

Although, there are abundant studies regarding the in vitro antioxidant activity of mushrooms (some edible mushrooms) with their phenolic contents (MAU et al., 2002; LO \& CHEUNG, 2005), the studies concerning in vivo antioxidant status of mushrooms on animals are very limited. In a previous study, GIANNENAS et al. (2010a) investigated the effects of powder $A$. bisphorus $(8.85 \mathrm{mg} \mathrm{GAE} / \mathrm{g})$ on growth performance and antioxidant status of broiler meat. They reported that dietary inclusion of $10 \mathrm{~g} / \mathrm{kg}$ or $20 \mathrm{~g} / \mathrm{kg}$ A. bisphorus reduced the malondialdehyde level in liver, breast and thigh meats while it increased glutathione peroxidase, reduced glutathione, glutathione S-transferase and glutathione reductase compared with the control group. Antioxidant-protective activity prevents lipid peroxidation, which is also a major cause of meat quality deterioration, affecting colour, flavour, texture, and nutritional value (GIANNENAS et al., 2010a). In a previous study by VETTER \& LELLEY (2004), the antioxidant effects of mushrooms were attributed to Se content. Unfortunately, mineral composition of mushroom parts was not analysed, especially selenium content. According to Table 5, the variability in meat quality parameters may not be due to the antioxidant activity of the mushroom because there are contradictions between our results and previous studies which were related to antioxidant activity and meat colour characteristics of mushroom supplementation in broilers. FERNANDEZ-LOPEZ et al. (2005) reported that increased $\mathrm{L}^{*}$ and decreased $\mathrm{a}^{*}$ values could be related to increasing metmyoglobin formation in the muscles. Antioxidants are substances that can decrease the oxidation rate of autoxidizable materials. The presence of natural antioxidant

Table 5 - The effects of dietary inclusion of mushroom on meat colour measurements $\left(\mathrm{L}^{*}, \mathrm{a}^{*}\right.$ and $\left.\mathrm{b}^{*}\right)$, $\mathrm{pH}$ and water holding capacity (WHC) in thigh and breast meats in broiler chickens.

\begin{tabular}{|c|c|c|c|c|c|c|}
\hline Parameters $\dagger$ & $\mathrm{C}$ & MM & MS & MC & SEM & $P$ \\
\hline \multicolumn{7}{|c|}{ 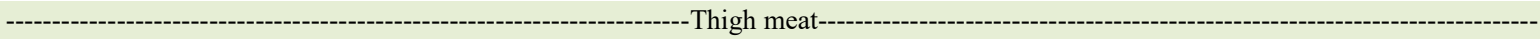 } \\
\hline $\mathrm{L}^{*}$, lightness & $58.27^{\mathrm{a}}$ & $52.39^{\mathrm{b}}$ & $54.82^{\mathrm{c}}$ & $56.39^{\mathrm{ab}}$ & 0.400 & $* *$ \\
\hline$a^{*}$, redness & $4.26^{\mathrm{a}}$ & $3.22^{\mathrm{b}}$ & $3.48^{\mathrm{b}}$ & $2.88^{\mathrm{b}}$ & 0.003 & $* *$ \\
\hline $\mathrm{b}^{*}$, yellowness & $3.68^{\mathrm{b}}$ & $3.91^{\mathrm{b}}$ & $4.26^{\mathrm{b}}$ & $6.08^{\mathrm{a}}$ & 0.047 & $*$ \\
\hline $\mathrm{pH}$ & $7.13^{b}$ & $7.19^{\mathrm{a}}$ & $7.21^{\mathrm{a}}$ & $7.12^{\mathrm{b}}$ & 0.011 & ** \\
\hline WHC & 11.58 & 10.84 & 11.56 & 12.06 & 0.427 & NS \\
\hline \multicolumn{7}{|c|}{ 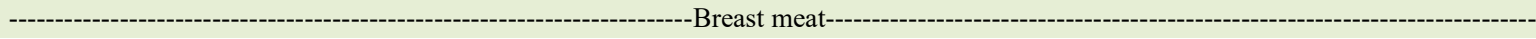 } \\
\hline $\mathrm{L}^{*}$, lightness & $50.20^{\mathrm{bc}}$ & $52.35^{\mathrm{ab}}$ & $52.87^{\mathrm{a}}$ & $49.48^{\mathrm{c}}$ & 0.414 & ** \\
\hline$a^{*}$, redness & $5.19^{\mathrm{a}}$ & $3.71^{b}$ & $3.66^{\mathrm{b}}$ & $4.03^{b}$ & 0.132 & $* *$ \\
\hline $\mathrm{b}^{*}$, yellowness & $4.69^{b c}$ & $5.30^{\mathrm{ab}}$ & $4.13^{\mathrm{c}}$ & $5.85^{\mathrm{a}}$ & 0.200 & $*$ \\
\hline $\mathrm{pH}$ & $6.56^{\mathrm{b}}$ & $6.71^{\mathrm{a}}$ & $6.59^{\mathrm{b}}$ & $6.68^{\mathrm{a}}$ & 0.016 & ** \\
\hline WHC & 13.84 & 13.15 & 11.85 & 12.01 & 0.584 & NS \\
\hline
\end{tabular}

${ }_{\mathrm{a}, \mathrm{b}, \mathrm{c}}$ Means in the same row not sharing a common letter are significantly different. NS: Not significant, ${ }^{*}: \mathrm{P}<0.05,{ }^{* *}: \mathrm{P}<0.01$. SEM: Standard error of mean.

$\dagger$ The values are means of the 4 replicates (pens).

${ }^{1}$ The dietary treatments were as following: control (C, basal diet without A. bisporus mushroom), A. bisporus mushroom mixture (MM, basal diet supplemented with $10 \mathrm{~g}$ mushroom stalk+10 g mushroom cap of per kg feed), A. bisporus mushroom stalk (MS, basal diet supplemented with $20 \mathrm{~g}$ MS of per kg feed) and A. bisporus mushroom cap (MC, basal diet supplemented with $20 \mathrm{~g}$ MC of per kg feed). 
compounds may retard metmyoglobin formation in meatballs and result in $\mathrm{a}^{*}$ decreased $\mathrm{L}^{*}$ value. Conversely, in the study, $\mathrm{L}^{*}$ values for the breast meat of animals fed with mushroom supplemented diets were increased, but a* values were decreased. These results indicated that other factors (phenolic substance, sugar composition, polysaccharide, vitamin A, Fe, Se etc.) in mushrooms may affect the meat colour quality. Therefore, in order to elucidate the effect of different parts of the mushroom on the breast and thigh meat colour, there is a need for detailed investigations about determining antioxidant capacities, physicochemical and chemical properties of the stalk and cap.

\section{CONCLUSION}

A. bisporus stalk meal can be used in broiler diets at $20 \mathrm{~g} / \mathrm{kg}$ with beneficial effects on the growth performance, intestinal morphology and meat quality. The positive results in the present study showed that the dietary inclusion of mushroom by-products in animal nutrition would fill the gap in animal feed shortages and help protect the environment. However, further studies are needed to determine the proper level of dietary A. bisporus stalk meal for broiler chickens. The adverse effects of mushroom caps on the growth performance and intestinal morphology in broilers also need to be investigated with detailed studies in future.

\section{ACKNOWLEDGEMENTS}

We acknowledge Kırșehir Ahi Evran University Office of Coordinatorship of Scientific Research Projects (Project No: PYO-ZRT.4006.12.001) for financial support of the study.

\section{BIOETHICS AND BIOSSECURITY COMMITTEE APPROVAL}

The study began after an ethics document was received from the Animal Experiments Local Ethics Committee of Ahi Evran University (AEU-HADYEK) dated 2/8/2016.

\section{DECLARATION OF CONFLICT OF INTEREST}

The authors declare no conflict of interest. The founding sponsors had no role in the design of the study; in the collection, analyses, or interpretation of data; in the writing of the manuscript, and in the decision to publish the results.

\section{AUTHORS' CONTRIBUTIONS}

All authors contributed equally to the conception and writing of the manuscript. All authors critically revised the manuscript and approved the final version.

\section{REFERENCES}

AOAC. Official methods of analysis of AOAC international. ABD: AOAC International. 2000.

ASADI-DIZAJI, A. et al. Effect of levels of oyster mushroom (Pleurotus ostreatus) on performance and blood biochemical characteristics in japanese quails (Coturnix coturnix). Iranian Journal of Applied Animal Science, v.7, n.4, p.687-691, 2017. Available from: <http://www.iaujournals.ir/article_535801.html $>$. Accessed: Jun. 01, 2021.

AVIAGEN. Ross 308 - Broiler nutrition specification. Midlothian, Scotland: Aviagen, 2014.

BEDERSKA- $Ł O J E W S K A, D$. et al. The use of Basidiomycota mushrooms in poultry nutrition-A review. Animal Feed Science and Technology, v.230, p.59-69, 2017. Available from: <https:// doi.org/10.1016/j.anifeedsci.2017.06.001>. Accessed: Jun. 01, 2021. doi: 10.1016/j.anifeedsci.2017.06.001.

CHERNO, N. et al. Chemical composition of Agaricus bisporus and Pleurotus ostreatus fruiting bodies and their morphological parts. Food and Environment Safety Journal, v.12, n.4, p.291299, 2016. Available from: <http://fia-old.usv.ro/fiajournal/index. php/FENS/article/view/180>. Accessed: Jun. 01, 2021.

$\mathrm{CHO}, \mathrm{M}$. et al. Effect of feeding zero-or high-tannin faba bean cultivars and dehulling on growth performance, carcass traits and yield of saleable cuts of broiler chickens. Journal of Applied Poultry Research, v.28, n.4, p.1305-1323, 2019. Available from: $<$ https://doi.org/10.3382/japr/pfz099>. Accessed: Jun. 01, 2021. doi: $10.3382 /$ japr/pfz099.

FAO. Food and agriculture data: 2019.

FARD, S. H. et al. Effect of oyster mushroom wastes on performance, immune responses and intestinal morphology of broiler chickens. International Journal of Recycling of Organic Waste in Agriculture, v.3, n.4, p.141-146, 2014. Available from: $<$ https://doi.org/10.1007/s40093-014-0076-9>. Accessed: Jun. 01, 2021. doi: $10.1007 / \mathrm{s} 40093-014-0076-9$.

FERNANDEZ-LOPEZ, J. et al. Antioxidant and antibacterial activities of natural extracts: application in beef meatballs. Meat Science, v.69, n.3, p.371-380, 2005. Available from: $<$ https://doi. org/10.1080/00071668.2018.1459041>. Accessed: Nov. 18, 2020. doi: $10.1080 / 00071668.2018 .1459041$.

GAUR, T. et al. Nutritional and anti-nutritional components of some selected edible mushroom species. Indian Journal of Natural Products and Resources, v.7, n.2, p.155-161, 2016. Available from: <http://nopr. niscair.res.in/handle/123456789/34565>. Accessed: Jun. 01, 2021.

GIANNENAS, I. et al. Performance and antioxidant status of broiler chickens supplemented with dried mushrooms (Agaricus bisporus) in their diet. Poultry Science, v.89, n.2, p.303-311, 2010a. Available from: <https://doi.org/10.3382/ps.2009-00207>. Accessed: Nov. 18, 2020. doi: 10.3382/ps.2009-00207.

GIANNENAS, I. et al. Influence of dietary mushroom Agaricus bisporus on intestinal morphology and microflora composition in broiler chickens. Research in Veterinary Science, v.89, n.1, p.78-84, 2010b. Available from: <https://doi.org/10.1016/j. rvsc.2010.02.003>. Accessed: Nov. 18, 2020. doi: 10.1016/j. rvsc.2010.02.003. 
GUNGOR, E. et al. Effect of raw and fermented grape pomace on the growth performance, antioxidant status, intestinal morphology, and selected bacterial species in broiler chicks. Animals, v.11, n.2, p.364, 2021. Available from: <https://doi. org/10.3390/ani11020364>. Accessed: Jun. 01, 2021. doi: 10.3390/ ani11020364.

GUNGOR, E.; G. ERENER. Effect of dietary raw and fermented sour cherry kernel (Prunus cerasus L.) on digestibility, intestinal morphology and caecal microflora in broiler chickens. Poultry Science, v.99, n.1, p.471-478, 2020. Available from: $<$ https://doi. org/10.3382/ps/pez538>. Accessed: Jun. 01, 2021. doi: 10.3382/ ps/pez538.

HAMMO, A. J. Effect of using for mushroom (Agaricus bisporus) agricultural by-products and its adding enzymes or without in rations on some productive and economical traits of broiler chicks. Research Journal of Pharmaceutical, Biological and Chemical Sciences, v.9, n.6, p.1001-1008, 2018. Available from: $<$ https://www.rjpbcs.com/pdf/2018_9(6)/[134].pdf $>$. Accessed: Jun. 01, 2021.

HSIEH, Y. C. et al. Effects of mushroom waster medium and stalk residues on the growth performance and oxidative status in broilers. Animal Bioscience, v.34, n.2, p.265, 2021. Available from: <https://doi.org/10.5713/ajas.19.0889>. Accessed: Jun. 01, 2021. doi: 10.5713/ajas.19.0889.

HUNT, M. C. et al. Guidelines for meat color evaluation. Chicago: National Livestock and Meat Board. 1991.

JAZI, V. et al. Effects of fermented cottonseed meal on the growth performance, gastrointestinal microflora population and small intestinal morphology in broiler chickens. British Poultry Science, v.58, n.4, p.402-408, 2017. Available from: <https://doi. org/10.1080/00071668.2017.1315051>. Accessed: Jun. 01, 2021. doi: $10.1080 / 00071668.2017 .1315051$.

KANNAN, G. et al. Effects of crating and transport on stress and meat quality characteristics in broilers. Poultry Science, v.76, n.3, p.523-529, 1997. Available from: <https://doi.org/10.1093/ ps/76.3.523>. Accessed: Nov. 18, 2020. doi: 10.1093/ps/76.3.523.

KAVYANI, A.; J. PORREZA. Evaluation of dried powder of mushroom (Agaricus bisporus) as an antibiotic growth promoter substitution on performance, carcass traits and humoral immune responses in broiler chickens. Journal of Medicinal Plants Research, v.6, n.1, p.94-100, 2012. Available from: <https:// doi.org/10.5897/JMPR11.1168>. Accessed: Jun. 01, 2021. doi: 10.5897/JMPR11.1168.

KAVYANI, A. et al. Efficiency of different levels of mushroom (Agaricus bisporus) on intestinal morphology and microflora of broiler chickens. Journal of Farm Animal Nutrition and Physiology, v.9, n.1, p.23-30, 2014. Available from: $<$ https://www. sid.ir/en/journal/ViewPaper.aspx?ID=360198>. Accessed: Jun. 01, 2021.

LEE, T.-T. et al. Effect of Pleurotus eryngii stalk residue on the oxidative status and meat quality of broiler chickens. Journal of Agricultural and Food Chemistry, v.60, n.44, p.11157-11163, 2012. Available from: <https://doi.org/10.1021/jf302740h>. Accessed: Jun. 01, 2021. doi: 10.1021/jf302740h.

LO, K. M.; P. C. K. CHEUNG. Antioxidant activity of extracts from the fruiting bodies of Agrocybe aegerita var. alba. Food
Chemistry, v.89, n.4, p.533-539, 2005. Available from: <https:// doi.org/10.1016/j.foodchem.2004.03.006>. Accessed: Nov. 18, 2020. doi: 10.1016/j.foodchem.2004.03.006.

MAU, J.-L. et al. Antioxidant properties of several medicinal mushrooms. Journal of Agricultural and Food Chemistry, v.50, n.21, p.6072-6077, 2002. Available from: $<$ https://doi.org/10.1021/ jf0201273>. Accessed: Nov. 18, 2020. doi: 10.1021/jf0201273.

NASIRI, F. et al. Comparative study on the main chemical composition of button mushroom's (Agaricus bisporus) cap and stipe. Journal of Food Biosciences and Technology, v.3, p.41-48, 2013. Available from: < https://api.semanticscholar.org/ CorpusID:56035959>. Accessed: Jun. 01, 2021.

OZTAN, A.; H. VURAL. A study on the changes of water holding capacity and the free water proportion of beef. Gida, v.18, p.29-33, 1993.

RAMOS, M. et al. Agaricus bisporus and its by-products as a source of valuable extracts and bioactive compounds. Food Chemistry, v.292, p.176-187, 2019. Available from: <https://doi. org/10.1016/j.foodchem.2019.04.035>. Accessed: Jun. 01, 2021. doi: 10.1016/j.foodchem.2019.04.035

SHAMSI, S. et al. Edible mushroom powder (Agaricus bisporus) and flavophospholipol improve performance and blood parameters of broilers. Revista Colombiana de Ciencias Pecuarias, v.28, n.4, p.291-302, 2015a. Available from: < https://doi.org/10.17533/ udea.rccp.v28n4a01>. Accessed: Jun. 01, 2021. doi: 10.17533/ udea.rccp.v28n4a01.

SHAMSI, S. etal.Effect of mushroom powder andflavophospholipol on carcass in broiler chickens. Revista Mexicana de Ciencias Pecuarias, v.6, n.4, p.469-481, 2015b. Available from: $<$ http://ref. scielo.org/qcyxx3>. Accessed: Jun. 01, 2021.

SHARMA, M. et al. Study on anti-nutritional contents and their effect on in vitro nutrient availability in Agaricus bisporus. Haryana Journal of Horticultural Sciences, v.37, n.3/4, p.274275, 2008. Available from: <https://www.cabdirect.org/cabdirect/ abstract/20143114871>. Accessed: Jun. 01, 2021.

SINGDEVSACHAN, S. K. et al. Mushroom polysaccharides as potential prebiotics with their antitumor and immunomodulating properties: A review. Bioactive Carbohydrates and Dietary Fibre, v.7, n.1, p.1-14, 2016. Available from: <https://doi. org/10.1016/j.bcdf.2015.11.001>. Accessed: Jun. 01, 2021. doi: 10.1016/j.bcdf.2015.11.001.

SINGH, P. K. Significance of phytic acid and supplemental phytase in chicken nutrition: a review. World's Poultry Science Journal, v.64, n.4, p.553-580, 2008. Available from: $<$ https://doi. org/10.1017/S0043933908000202>. Accessed: Jun. 01, 2021. doi: $10.1017 / \mathrm{S} 0043933908000202$.

SIU, K.-C. et al. Constituents actually responsible for the antioxidant activities of crude polysaccharides isolated from mushrooms. Journal of Functional Foods, v.11, p.548-556, 2014. Available from: $<$ https://doi.org/10.1016/j.jff.2014.08.012>. Accessed: Jun. 01, 2021. doi: 10.1016/j.jff.2014.08.012.

SMOLSKAITÉ, L. et al. Comprehensive evaluation of antioxidant and antimicrobial properties of different mushroom species. LWT-Food Science and Technology, v.60, n.1, p.462-471, 2015. Available from: <https://doi.org/10.1016/j.lwt.2014.08.007>. Accessed: Jun. 01, 2021. doi: 10.1016/j.lwt.2014.08.007. 
ŠPOLJARIĆ, D. et al. The effects of feed supplemented with Agaricus bisporus on health and performance of fattening broilers. Veterinarski Arhiv, v.85, n.3, p.309-322, 2015. Available from: $<$ https://hrcak.srce.hr/141037>. Accessed: Jun. 01, 2021.

TOGHYANI, M. et al. Evaluation of oyster mushroom (Pleurotus ostreatus) as a biological growth promoter on performance, humoral immunity, and blood characteristics of broiler chicks. The Journal of Poultry Science, v.49, n.3, p.183-190, 2012. Available from: <https://doi.org/10.2141/jpsa.011068>. Accessed: Nov. 18, 2020. doi: $10.2141 /$ jpsa.011068.

VAN SOEST, P. J. V. et al. Methods for dietary fiber, neutral detergent fiber, and nonstarch polysaccharides in relation to animal nutrition. Journal of Dairy Science, v.74, n.10, p.35833597, 1991. Available from: <https://doi.org/10.3168/jds.S00220302(91)78551-2>. Accessed: Nov. 18, 2020. doi: 10.3168/jds. S0022-0302(91)78551-2.

VETTER, J.; J. LELLEY. Selenium level of the cultivated mushroom Agaricus bisporus. Acta Alimentaria, v.33, n.3, p.297-301, 2004. Available from: <https://doi.org/10.1556/
AAlim.33.2004.3.10>. Accessed: Nov. 18, 2020. doi: 10.1556/ AAlim.33.2004.3.10

WU, X. et al. Effects of UV-C on antioxidant activity, total phenolics and main phenolic compounds of the melanin biosynthesis pathway in different tissues of button mushroom. Postharvest Biology and Technology, v.118, p.51-58, 2016. Available from: $<$ https://doi. org/10.1016/j.postharvbio.2016.03.017>. Accessed: Jun. 01, 2021. doi: 10.1016/j.postharvbio.2016.03.017.

XU, Z. R. et al. Effects of fietary fructooligosaccharide on digestive enzyme activities, intestinal microflora and morphology of male broilers. Poultry Science, v.82, n.6, p.1030-1036, 2003. Available from: <https://doi.org/10.1093/ps/82.6.1030>. Accessed: Nov. 18, 2020. doi: $10.1093 / \mathrm{ps} / 82.6 .1030$.

YANG, B. et al. Effects of the Agaricus bisporus stem residue on performance, nutrients digestibility and antioxidant activity of laying hens and its effects on egg storage. Animal Bioscience, v.34, n.2, p.256, 2021. Available from: <https:// doi.org/10.5713/ajas.19.0853>. Accessed: Jun. 01, 2021. doi: 10.5713/ajas.19.0853. 